\title{
Chapter 4 \\ Mutation Induction Using Gamma \\ Irradiation and Embryogenic Cell \\ Suspensions in Plantain (Musa spp.)
}

\author{
Jorge López, Aymé Rayas, Arletys Santos, Víctor Medero, Yoel Beovides, \\ and Milagros Basail
}

\begin{abstract}
Bananas and plantains (Musa spp.) are among the world's most important crops and are considered as a poor man's crop in tropical and subtropical countries. For this reason, they play a very important role in tropical regions' food security. Several pathogens throughout the tropical areas of the world have become a threat for production, including "black sigatoka" (Mycosphaerella fijiensis Morelet) which is the most damaging disease for Musa plantations in Cuba. It is present in all areas of the country, and it replaced "sigatoka disease" (Mycosphaerella musicola) as the main threat. Chemical control and cultural practices reduce damages, but they are not solving the problem. Genetic variations are the basic tools to develop new cultivars with better traits, such as tolerance against various environmental stresses, resistance against pests and diseases, and improved yield and quality. Tissue culture techniques offer the opportunity for variation induction, handling of large plant populations using established selection methods, and rapidly cloning selected variants. All these strategies can increase the efficiency of mutagenic treatments and subsequent screening of mutant materials. Somatic embryogenesis (SE) is also an excellent system for clonal propagation and mutation induction. The present chapter describes a protocol on how to use embryogenic cell suspensions (ECS) in plantain (Musa spp.) using both in vitro gamma irradiation and plant regeneration in order to achieve genetic improvement. The process involves a series of steps to properly select ECS for irradiation and the posttreatment handling for plant regeneration as well as mutant selection during acclimatization phase and under field conditions.
\end{abstract}

Keywords Breeding • In vitro mutagenesis • Radiosensitivity testing • Somatic embryogenesis

\footnotetext{
J. López $(\varangle) \cdot$ A. Rayas • A. Santos • V. Medero • Y. Beovides • M. Basail Instituto de Investigaciones de Viandas Tropicales (INIVIT), Apdo 6, Santo Domingo,

Villa Clara CP 53000, Cuba

e-mail: lab.cell.biotec@inivit.cu
} 


\subsection{Introduction}

Bananas and plantains (Musa spp.) are important staple crops. Over 400 million people throughout tropical and subtropical areas of the developing countries depend on these crops as a major source of calories and as an important commodity for local and international trade. Several pathogens throughout the tropical regions have become a threat for banana and plantain (Musa spp.) production (Suprasanna et al. 2012). In Cuba, this is a high-priority crop as part of the national food system because of its ability to produce all year round, its high per capita consumption rate, and the diversity of its uses. However, the country faces persistent low yields which are mainly attributed to attacks of "black sigatoka" disease caused by the fungal pathogen Mycosphaerella fijiensis. Because of disease damages and poor-quality planting materials, plantains (AAB group) are being gradually replaced by other more resistant variants, such as cooking bananas of the ABB Musa group and tetraploid hybrids (López et al. 2013).

Breeding banana and plantain for resistance to diseases and pest is urgently needed by small-scale and commercial producers. However, these crops have very low clonal multiplication rates, and most of the commercial varieties are polyploid, with extremely poor seed production. These barriers impede sexual hybridization and consequently slow down genetic improvement of the crop (Bakry et al. 2009; Okole 2010). The heterozygotic status is expected to be Aa in loci of diploid cultivars, while the triploids of A genomic types can exist in either Aaa or AAa forms. For interspecific hybrids, the heterozygotic constitution could be AaB, Aab, $\mathrm{AAb}, \mathrm{ABb}, \mathrm{aBb}$, or aBB. Mutation induction may uncover a recessive phenotype by mutating, inhibiting, or deleting the corresponding dominant allele (Jain and Swennen 2004).

The success of any in vitro mutagenesis programme depends on the establishment of reproducible in vitro plant regeneration procedures, optimization of mutagenic treatments, and efficient screening of the mutagenized populations for desired variations (Jain 2007; Xu et al. 2012). Somatic embryogenesis (SE) is an excellent system for clonal propagation and mutation induction. The fact that somatic embryos originate from a single cell prevents chimaeras among regenerated plants and makes them an ideal subject for mutagenesis (Jain 2010). It has been shown that somatic embryos arising from banana cell suspensions most "probably" have a single-cell origin (Roux et al. 2004). Thus, the main advantage of using the ECS for mutagenesis would be either in obtaining non-chimaeric populations or the quick dissociation of the chimaeric sectors if any (Roux et al. 2001).

\subsubsection{Somatic Embryogenesis in Musa spp.}

SE is a process in which bipolar structures resembling a zygotic embryo develop from a non-zygotic cell without vascular connections with the original tissue. It is 
an important system where multiplication can be done at enormous rates (Arnold et al. 2002). During their development, SE passes through four consecutive phases: (1) induction of SE, (2) somatic embryo formation, (3) maturation of somatic embryo, and (4) somatic embryo germination and conversion into viable plantlets (Parrott 1993).

$\mathrm{SE}$ is a promising method for the establishment of protocols reaching rapid multiplication of new and elite genotypes and synthetic "seed" production. In vitro selection uses various biotic and abiotic stresses in order to study genetic manipulation (Kamle et al. 2011). In Musa, SE has been obtained by different ways. They include cultures of zygotic embryos (Cronauer and Krikorian 1988; Escalant and Teisson 1988), leaf tissues and rhizome (Novak et al. 1989a), highly proliferating meristems (Dhed'a et al. 1991; Schoofs 1997), male inflorescences (Ma 1991; Escalant et al. 1994), and female inflorescences (Grapin et al. 1998). The most successful explants were the proliferating meristems and male inflorescences. They allow for the establishment of ECS, the formation of somatic embryos, and their subsequent conversion into plants that undergo field evaluation (Strosse et al. 2003; Aguilar et al. 2008).

Although SE in banana is now a well-established method (Strosse et al. 2003; Aguilar et al. 2008), the initiation of a "genotype-independent" embryogenic cell culture is still far from routine (Schoofs et al. 1999; Kulkarni et al. 2007). It is difficult to have an efficient and repeatable protocol for all Musa genomic groups. López (2006) developed a protocol for plantain cultivars that do not have the male inflorescence (Horn and Pseudo-horn type). This protocol is based on the use of shoot apices (explant) from the multiplication of the axillary buds in the presence of ancymidol (0.2-0.4 $\mathrm{mg} \mathrm{l}^{-1}$ depending on the cultivar). It also relies on the somatic embryos' ability to achieve differentiation in semisolid and liquid culture media. The use of shoot apices of axillary buds to induce ECS in AAB group plantain cultivars in Cuba prompted the scaling up of propagation by SE to biofactories (commercial laboratories) that are being established as an alternative for clonal propagation (López et al. 2013) and its application in the banana genetic improvement programme by mutations (López et al. 2007; Sales et al. 2013).

\subsubsection{Mutation Induction in Musa spp.}

Biotechnology, while making use of both mutagenesis and conventional methods, can assist in overcoming hurdles during the development of new and improved banana cultivars for sustainable fruit production. This in turn improves the socioeconomic status of growers (Jain and Maluszynski 2004). The most commonly used mutagens so far are physical mutagens such as gamma rays (Roux 2004). The Musa mutation induction system based on in vitro techniques to obtain mutant plants and micropropagate desirable mutants was developed by Novak et al. (1989b). Later, Roux (2004) standardized the methodology to provide guidelines to mutation induction programmes in Musa spp. Shoot tips were excised from clones 
representing different genomic constitutions of the genus Musa. Later, they were treated with ten doses from 10 to $100 \mathrm{~Gy}$ of a cobalt-60 source at a dose rate of $44 \mathrm{~Gy} / \mathrm{min}$. Radiation sensitivity and postirradiation recovery were assessed by measuring survival rate, propagation rate, shoot height, and fresh weight. The different Musa accessions showed different responses depending on the ploidy level and genomic constitution. The following ranges of doses were recommended: 10-20 Gy for diploid cultivars (AA and BB), 30-40 Gy for triploid cultivars (AAA and AAB), and 40-50 Gy for triploid cultivars (ABB) (Roux 2004).

In vitro mutagenesis of multicellular meristems of Musa spp. can lead to a high degree of chimaerism. The regenerated mutant plants will be potentially unstable in regard to cellular genotypes and expressed phenotypes due to segregation in subsequent vegetative propagated generations. Interestingly, data from chemical mutagenesis of triploid bananas suggests that chimaerism can be quickly resolved and may not be an issue in some cases (Jankowicz-Cieslak et al. 2012). Similar data is not available for gamma irradiation, and therefore several rounds of subculturing are advised to remove chimaeras (see Chap. 3 for more on chimaera dissolution in banana). Once subculturing is completed, the rooted plantlets are weaned in the greenhouse and planted in the fields for evaluation (Kulkarni et al. 2007).

The main advantage of using the ECS for in vitro mutagenesis treatment is the instant production of non-chimaeric populations or the quick dissociation of the chimaeric sectors if they are found. Using this process can therefore increase the efficiency of mutagenic treatments (Roux et al. 2001). There are only a few available reports on gamma irradiation for ECS in Musa spp. (López et al. 2007; Roux 2004; Kulkarni et al. 2004). The time at which the cells are irradiated is very critical, according to Roux et al. (2004) and Kulkarni et al. (2007). The optimal timing for irradiation is considered to be 4-6 days after subculture because at this time the majority of cells are in the G1 phase. One of the most important steps in mutagenesis experiments is to determine the appropriate dose. Theoretically, LD50 will cause the highest frequency of mutations (Van Harten 1998). Studies on irradiated embryogenic cell suspension from cultivars "CEMSA 3/4" (AAB) and "Calcutta 4" (AA) showed that the LD50 should be calculated during the embryo germination stage (sprouts and roots emission) (López et al. 2007; Sales et al. 2013).

The irradiated ECS survival has been too high and variable. Roux et al. (2004) stated that the ECS of cultivars "Williams" and "Three Hand Planty" grew even at a very high dose of 250 Gy. Kulkarni et al. (2004) observed that a 40 Gy dose in cv. "Gran Nain" was completely lethal. Due to the higher hydration levels, the ECS were more radiosensitive. However, previous reports indicate that gamma irradiation at approximately 70 Gy was completely lethal to the shoot-tip multiples.

When searching for a desired trait, mutation induction protocols should aim to increase the degree of plant's genetic diversity within the resulting plant population. In order to accomplish this goal, it is necessary to continue integrating the gamma ray mutagenesis processes with selection of in vitro cell lines or tissue cultures using a selection agent (e.g. a medium with a high concentration of salt or 
phytotoxin). The present chapter describes a protocol for plant regeneration from ECS in plantain (Musa spp.) and its use for in vitro mutagenesis.

\subsection{Materials}

\subsubsection{Explant Preparation: Shoot-Tip Establishment and Multiplication}

1. Donor plants for in vitro establishment (culture initiation). Materials used for this protocol were taken from the germplasm bank with previous characterization by descriptors for banana Musa spp. (INIBAP 1996).

2. Semi-controlled growth environment (shade or screen house).

3. Detergent dish soap in water ( $20 \mathrm{~g}$ for 100 explants).

4. Sodium hypochlorite $(\mathrm{NaOCl}) 2.5$ and $3 \%$ in water.

5. Laminar airflow cabinet.

6. Dissecting instruments (scalpels with removable blades and forceps).

7. Culture tubes $(150 \times 25 \mathrm{~mm})$.

\subsubsection{Culture Medium and Incubation Materials}

1. Murashige and Skoog mineral salts (MS) (Murashige and Skoog 1962) (see Note 1 and Table 4.1).

2. Balance.

3. $\mathrm{pH}$ meter.

4. Autoclave.

5. Culture tubes $(150 \times 25 \mathrm{~mm})$.

6. Petri dishes $(80 \times 15 \mathrm{~mm})$.

7. Erlenmeyer flasks $(10$ and $100 \mathrm{ml})$.

8. Plastic mesh with $100 \mu \mathrm{m}$ holes.

9. Temporal immersion system, type Rita ${ }^{\circledR}$ of $500 \mathrm{ml}$ capacity.

10. Laminar airflow cabinet.

11. Dissecting instruments (scalpels with removable blades, and forceps).

12. Stereo microscope and inverted microscope.

13. Rotary shaker (70-100 rpm).

14. Growth chamber or a windowless room with environmental control. Specific details for culture room conditions in each stage of the protocol are given in Table 4.2 (see Note 2). 


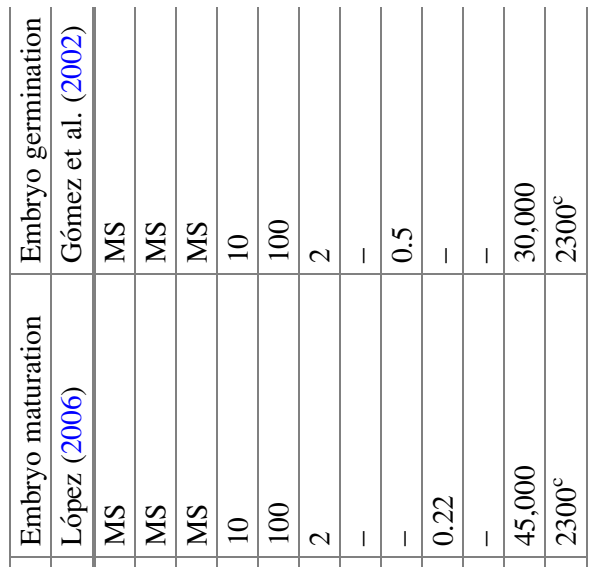

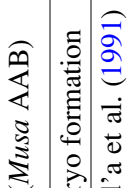

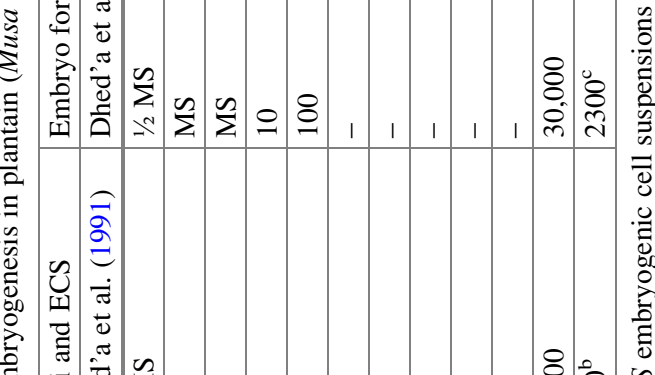

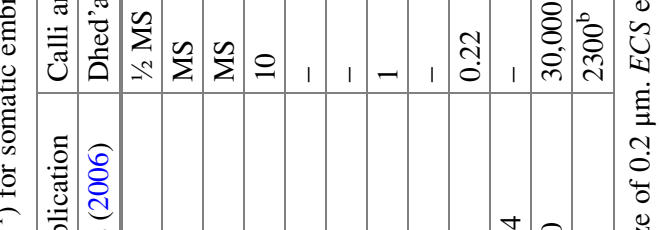

I.

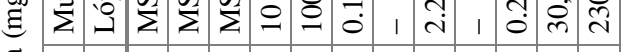

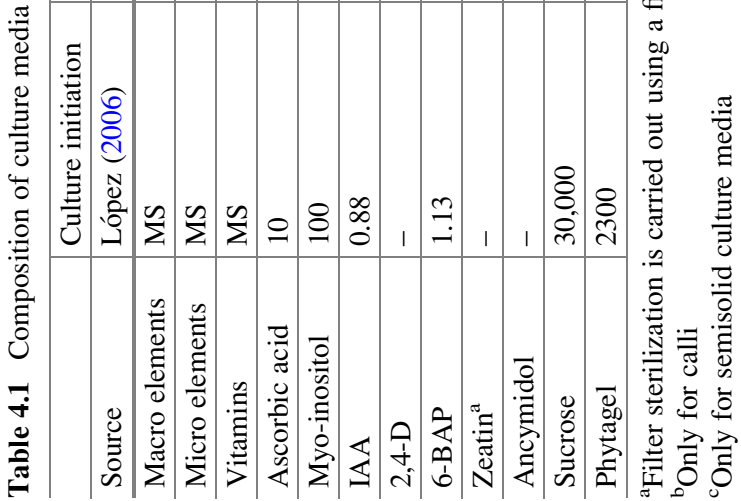


Table 4.2 Culture conditions for plant regeneration by somatic embryogenesis in plantain (Musa $\mathrm{AAB})$

\begin{tabular}{|c|c|}
\hline Stages & Culture room conditions \\
\hline $\begin{array}{l}\text { - Establishment and multiplication of shoot tip } \\
\text { in semisolid culture media } \\
\text { - Formation of somatic embryos in semisolid } \\
\text { culture media } \\
\text { - Germination of somatic embryos in tempo- } \\
\text { rary immersion system and semisolid culture } \\
\text { media }\end{array}$ & $\begin{array}{l}\text { Cultures are maintained on open shelves in } \\
\text { climate-controlled laboratories }\left(25 \pm 2{ }^{\circ} \mathrm{C}\right) \text {. } \\
\text { Shelves are lighted with } 40 \mathrm{~W} \text { cool white } \\
\text { fluorescent lamps providing } 62-68 \mu \mathrm{mol} \mathrm{m} \mathrm{m}^{-2} \\
\mathrm{~s}^{-1} \text { of photosynthetic photon flux density } \\
\text { under } 16 / 8 \text { light and dark }\end{array}$ \\
\hline $\begin{array}{l}\text { - Callus formation with embryogenic structures } \\
\text { in semisolid culture media } \\
\text { - Maturation of somatic embryos in semisolid } \\
\text { culture media }\end{array}$ & $\begin{array}{l}\text { Cultures are maintained on closed shelves in } \\
\text { climate-controlled laboratories }\left(25 \pm 2{ }^{\circ} \mathrm{C}\right) \text { in } \\
\text { dark }\end{array}$ \\
\hline $\begin{array}{l}\text { - Establishment and multiplication of embryo- } \\
\text { genic cell suspensions } \\
\text { - Formation of somatic embryos in liquid } \\
\text { culture media } \\
\text { - Maturation of somatic embryos in liquid } \\
\text { culture media }\end{array}$ & $\begin{array}{l}\text { Explants were put on an orbital shaker at } \\
90 \mathrm{rpm} \text { in climate-controlled laboratories } \\
\left(25 \pm 2{ }^{\circ} \mathrm{C}\right) \text {, lighted with } 40 \mathrm{~W} \text { cool white } \\
\text { fluorescent lamps providing } 62-68 \mu \mathrm{mol} \mathrm{m}{ }^{-2} \\
\mathrm{~s}^{-1} \text { of photosynthetic photon flux density } \\
\text { under } 16 / 8 \text { light and dark }\end{array}$ \\
\hline
\end{tabular}

\subsubsection{Acclimatization}

1. Regenerated plantlets

2. 3.51 black polyethylene bags $(15 \mathrm{~cm}$ diameter, $20 \mathrm{~cm}$ high)

3. Substrates: filter press mud or soil to compost mixture $(1: 1 \mathrm{v} / \mathrm{v})$

4. Urea

5. Acclimatization phase

\subsubsection{Mutation Induction Using Gamma Irradiation}

1. Cobalt-60 source

2. Embryogenic cell suspensions

3. $1000 \mu \mathrm{m}$ pore-size mesh

4. $2.0 \mathrm{ml}$ Eppendorf plastic tubes

5. Petri dishes $(80 \times 15 \mathrm{~mm})$

6. Culture tubes $(150 \times 25 \mathrm{~mm})$ 


\subsection{Methods}

\subsubsection{Explant Preparation: Shoot-Tip Establishment and Multiplication}

\subsubsection{Shoot-Tip Establishment}

1. Remove "sword" suckers between 25 and $30 \mathrm{~cm}$ in height from healthy flowering donor plants.

2. Grow material under semi-controlled conditions for 45-60 days until vigorous and healthy-looking suckers of $15-25 \mathrm{~cm}$ in height with a corm diameter of about $10 \mathrm{~cm}$ are observed. Also, smaller buds (sleeping eyes) on the corm can be used as explants for tissue culture initiation as an alternative to increase the seed volume at the initial stage.

3. Remove leaf sheaths from the corm to obtain 4-5 cm diameter sections enclosing the vegetative apex. Wash the tissue cubes under running tap water.

4. Rinse four times with detergent (20 g by 100 explants) and disinfect explants with sodium hypochlorite (3\%) plus $4 \mathrm{ml}$ ethanol $(95 \%)$ for $20 \mathrm{~min}$. Swirl the solution frequently (see Note 3 ).

5. Decant the hypochlorite solution. Rinse explants three times during 3-4 min with sterile deionized water and decant.

6. Explants are reduced to $2.5-3 \mathrm{~cm}$ high with a square base of about $1.5 \mathrm{~cm}$ and transfer (the explants) to a laminar airflow cabinet followed by a second disinfection for $10 \mathrm{~min}$ with $2.5 \% \mathrm{NaOCl}$. Decant the hypochlorite solution and wash explants three times with sterile distilled water.

7. Apices are reduced to a rectangular shape of $1.0 \times 0.5 \mathrm{~cm}$ and are inoculated in culture tubes containing $10 \mathrm{ml}$ of establishment culture medium for 15-18 days (Tables 4.1 and 4.2) (López 2006).

\subsubsection{Shoot-Tip Multiplication}

1. First subculture: The shoot tips are cut longitudinally through the apex after in vitro establishment period (15-18 days) and are inoculated in culture tubes containing $10 \mathrm{ml}$ multiplication culture medium for 21-30 days.

2. Second subculture: Shoot tips are decapitated from 2 to $3 \mathrm{~mm}$ from the corm base, and sprouts smaller than $15 \mathrm{~mm}$ are not separated from each other and are not decapitated. They are inoculated in culture tubes containing $10 \mathrm{ml}$ multiplication culture medium for 21-30 days. At this stage, shoot-tip multiplication is stimulated through multiple subcultures to obtain shoot proliferation.

3. Third subculture: Multiplication is followed as in the second subculture. Through repeated subcultures, the multiplication of propagules follows an exponential increment pattern until the desired number of propagules is reached. From this subculture, shoot tips are used for inducing SE process. 


\subsubsection{Protocol for Plant Regeneration via Somatic Embryogenesis}

This protocol involves a series of sequential stages: obtaining explants (multiplication of shoot-tip cultures, see Sect. 4.3.1); callus formation with embryogenic structures; establishment and multiplication of ECS; formation, maturation, and germination of embryos (Tables 4.1 and 4.2); conversion to plants; and field evaluation (López 2006) (Fig. 4.1).

\subsubsection{Callus Formation with Embryogenic Structures}

Shoot tips are excised from axillary buds $(2-3 \mathrm{~mm})$ with the aid of a stereoscopic microscope for callus formation with embryogenic structures. They are incubated in culture tubes with $10 \mathrm{ml}$ of culture medium for callus formation during 3-8 months (see Note 4).

\subsubsection{Establishment and Multiplication of Embryogenic Cell Suspensions}

1. Use proembryos and embryos in the globular stage obtained from callus with embryogenic structures [0.08-0.1 g fresh weight $(\mathrm{gFW})]$ to establish ECS. Incubation is performed in $10 \mathrm{ml}$ Erlenmeyer flask with 2-3 $\mathrm{ml}$ of suspensions culture medium (Santos et al. 2002). Media renewals (50\%) are carried out every 3 days to eliminate the presence of non-embryogenic cell aggregates and died cells. Cultures are placed on an orbital shaker at $90 \mathrm{rpm}$.

2. After 20-30 days, cellular cultures formed are sieved through filters of $500 \mu \mathrm{m}$ metallic mesh. At this moment homogeneous cell suspensions are formed.

3. The multiplication of ECS is carried out at $3 \%$ settle cell volume (SCV) and subcultured each 15 days. Incubation is performed in $100 \mathrm{ml}$ Erlenmeyer flasks (López 2006; López et al. 2005a) (see Note 5). Culture media and culture conditions are similar to those applied in the establishment of ECS.

\subsubsection{Formation of Somatic Embryos}

ECS from the exponential or linear growth phase is used for somatic embryos formation in semisolid or liquid culture media:

1. Somatic embryo formation in semisolid culture media is obtained by incubating a drop of ECS on Petri dishes. ECS have been previously diluted in $25 \%$ SCV. Four $100 \mu \mathrm{m}$ pore-size plastic meshes are placed on each Petri dish. Each mesh has a $1 \mathrm{~cm}^{2}$ size to four one cell drop at $25 \% \mathrm{SCV}$ incubate during a 4-6 weeks period. 


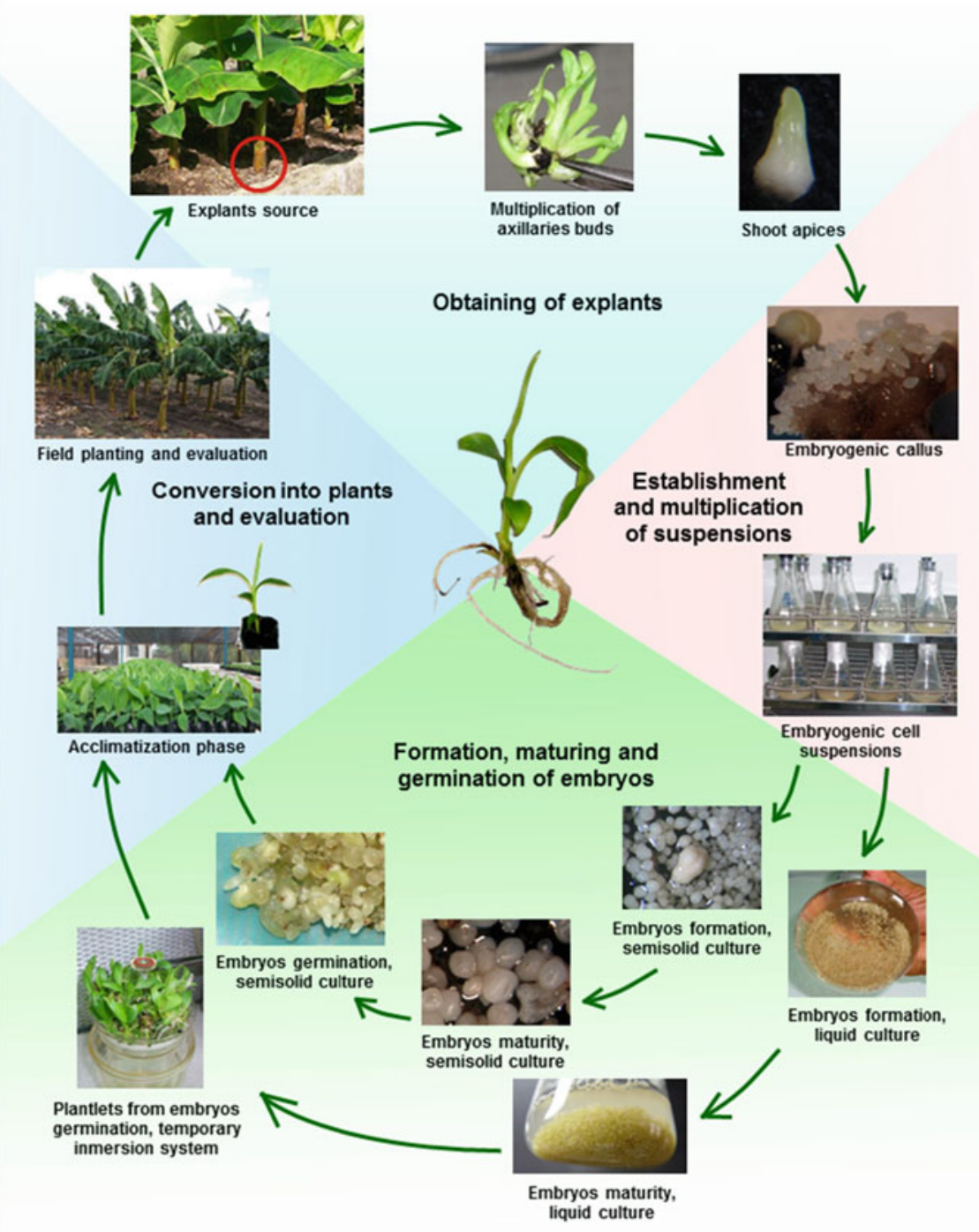

Fig. 4.1 Steps for developing somatic embryogenesis in Musa AAB cultivars

2. For somatic embryos formation in liquid culture medium SCV is adjusted to $12 \%$. Keep culture for 4-6 weeks. Culture medium is renewed every 15 days.

\subsubsection{Maturation of Somatic Embryos}

1. Maturation of somatic embryos in semisolid culture media 
Embryogenic mass portions $(0.3-0.4 \mathrm{~mm})$ from somatic embryos in the globular stage form in semisolid culture media and are incubated during a month on Petri dish for somatic embryos maturation.

2. Maturation of somatic embryos in liquid culture media

In order to obtain matured somatic embryos: $0.5 \mathrm{gFW}$ of somatic embryos from the globular stage in liquid culture media are incubated on $30 \mathrm{ml}$ of maturing culture medium in $100 \mathrm{ml}$ Erlenmeyer flask during a month. Culture medium is renewed after 15 days of culture.

\subsubsection{Germination of Somatic Embryos}

1. Germination of somatic embryos in semisolid culture media

Mature somatic embryos with visible invagination at a stereo microscope are incubated for a month on Petri dish containing semisolid culture medium for somatic embryo germination.

2. Germination of somatic embryos in temporal immersion system, type Rita ${ }^{\circledR}$ (see Note 6)

The temporal immersion system, type Rita ${ }^{\circledR}$ [developed by Teisson and Alvard (1995) with $200 \mathrm{ml}$ culture medium for germination], is used for germination of somatic embryos according to López (2006). The immersion frequency was three times daily, during $1 \mathrm{~min}$ each according to Escalant et al. (1994). For every temporal immersion system, use an inoculant density of $0.5 \mathrm{~g}$ fresh weight of somatic embryo (gFW). Incubate during a 25-30 days period.

\subsubsection{Acclimatization Phase of Somatic Embryos, Conversion into Plants}

In order to carry out somatic embryo conversion into plants, the following conditions must be guaranteed for plantlets coming from in vitro:

1. Keep relative humidity above $80 \%$ within the first 10 days after transplanting to acclimatization phase.

2. Protect plants from direct sunlight incidence with zaran to allow light intensity of $600 \mu \mathrm{mol} \mathrm{m} \mathrm{m}^{-2} \mathrm{~s}^{-1}$. Gradually, these conditions must be reduced to achieve full plant adaptation to field conditions.

For somatic embryos conversion into plants, the following procedures are followed:

1. Plantlets are removed from the culture vessel. 
2. Wash the plantlets carefully to remove residual culture media and separate them into individual plants. Classify plants by size for planting (large: more than $5 \mathrm{~cm}$ high; medium: 3-5 cm; and small: less than $3 \mathrm{~cm}$ ).

3. Transplant plantlets into polyethylene bags containing filter press mud or soil compost mixture $(1: 1 \mathrm{v} / \mathrm{v})$.

4. Fertilize with foliar urea $5 \mathrm{~g} \mathrm{l}^{-1}$ after 15 days and every 7 days until transplanting to field conditions.

5. Plantlets are kept in the acclimatization phase for 45-60 days until they reach a height of around $15 \mathrm{~cm}$. At this time, they are suitable to plant out in the field.

\subsubsection{Mutation Induction Using Gamma Irradiation}

Mutation induction is achieved by exposing ECS to gamma irradiation. Mutant selection occurs both during the acclimatization phase and under field conditions (López et al. 2007; Sales et al. 2013) (Fig. 4.2). The whole process for irradiation of ECS is detailed below:

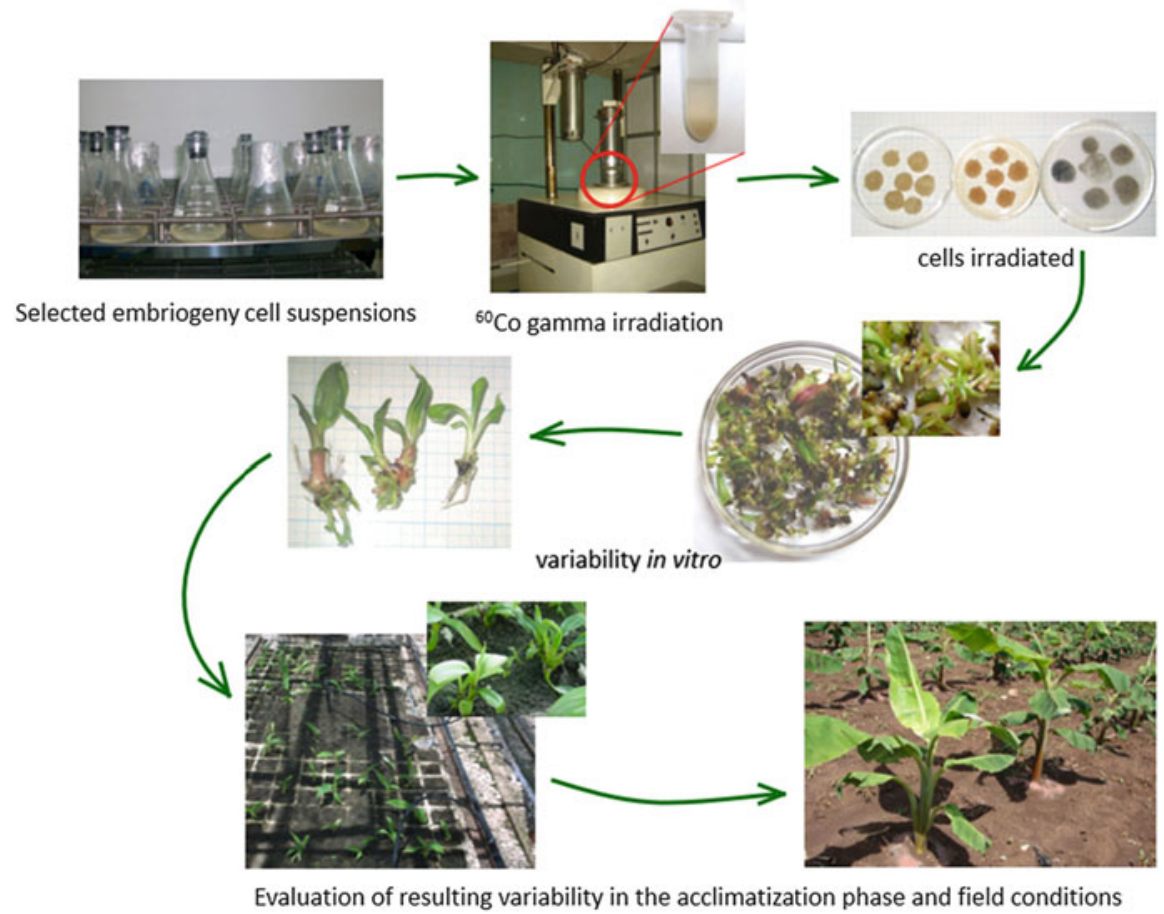

Fig. 4.2 Use of embryogenic cell suspensions (Musa AAB) for in vitro mutagenesis 
1. Selected ECS with stable growth and proven ability to regenerate plants are taken 4 days after subculture and are sieved through $1000 \mu \mathrm{m}$ pore-size mesh.

2. Add $0.4 \mathrm{ml}$ cells to each $2.0 \mathrm{ml}$ Eppendorf plastic tubes (three per each irradiation dose) to irradiate using a cobalt-60 gamma source (0-100 Gy, in steps of $10 \mathrm{~Gy})$.

3. Incubate irradiated ECS and the nonirradiated control in semisolid medium for somatic embryos formation during 30-40 days.

Incubation of each treatment to promote somatic embryo formation occurs as follows: Each Eppendorf plastic tube contains four plantings coming from a single Petri dish. Each study treatment includes three Eppendorf tubes with a total of three Petri dishes per treatment.

4. Transfer somatic embryos formed to a semisolid maturing medium for somatic embryos maturation. Keep them in maturing medium for 30 days.

5. Transfer matured somatic embryos to a semisolid medium in order to promote germination. Keep them in semisolid medium for 30 days. At this stage, calculate the LD50 for germinated embryos (see Note 7).

6. Transfer germinated embryos (plantlets) to the acclimatization phase to promote plant conversion. Survival of plantlets from irradiated ECS and phenotypic changes are evaluated and compared with plantlets obtained from nonirradiated ECS (control) according to the methodology proposed by Sandoval et al. (1997) and López et al. (2005b).

The following parameters are tested 60 days after transplantation:

- Survival rate

- Plant height $(\mathrm{cm})$

- Petiole length of the second leaf $(\mathrm{cm})$

- Length of the second leaf $(\mathrm{cm})$

- Width of the second leaf $(\mathrm{cm})$.

- Distance between the second and third leaf $(\mathrm{cm})$

7. Transfer plantlets from irradiated ECS, plantlets from nonirradiated ECS (control), and corm buds (also as control) to field conditions in order to evaluate the resulting variability and possible mutants according to Sandoval et al. (1997) and López et al. (2005b).

The following parameters are tested 6 months after planting and during harvest:

- Pseudostem circumference at a meter height $(\mathrm{cm})$

- Plant height $(\mathrm{cm})$

- Number of active leaves

- Flowering date (weeks)

- Number of fingers/bunch

- Number of hands/bunch

- Bunch weight

- Length of the central finger in the second hand $(\mathrm{cm})$ 
- Length of the central finger in the next to the last hand $(\mathrm{cm})$

- Length of the central finger in the last hand $(\mathrm{cm})$

- Incidence of "black sigatoka" at the flowering time according to some criterions for the Technical Guidelines 7 from INIBAP (Carlier et al. 2003).

8. Multiply and evaluate possible mutants selected from the first cycle during a second field crop (INIBAP 1996).

\subsection{Notes}

1. Mineral salts from Murashige and Skoog medium (Murashige and Skoog 1962) are very suitable for banana and plantain shoot-tip culture and SE (Table 4.1). Culture media are prepared by dissolving all media components in a flask with distilled water. $\mathrm{pH}$ values are adjusted to 5.8 in all media by using $\mathrm{HCl}$ and $\mathrm{KOH}$. For medium solidification, $2300 \mathrm{mg}^{-1}$ of Phytagel is added to and dissolved in the medium by heating it on the stirring/hot plate. The medium is dispensed into tissue culture vessels, and then it is sterilized for 15-30 min depending on the size of culture vessels $\left(121{ }^{\circ} \mathrm{C} \times 1.2 \mathrm{~kg} \mathrm{~cm}^{-2}\right)$.

2. A windowless room having a controlled environment is necessary to keep in vitro cultures. An air conditioning unit is suitable for temperature control, and the photoperiod is also controlled with artificial lighting.

3. It is important to have enough active substance, capable of reacting with the surface of the vegetable material. To accomplish this, the amount of $\mathrm{NaOCl}$ added for disinfection needs to be two to three times higher than the number of apices disinfected.

4. The formation of embryogenic cultures is observed after 3 months. It is characterized by yellow meristematic globules (nodular calli) with and without embryo formation in the meristematic globule surface similar to those described by Dhed'a et al. (1991) and Schoofs (1997).

5. During the multiplication stage, cell suspensions are characterized by many spherical cells in active division. Cell aggregates might be heterogeneous, irregular, translucent, and non-translucent. The abovementioned cell characteristics are considered indicators of embryogenic conditions for cell suspensions (Dhed'a et al. 1991).

6. Temporal immersion system shows better performance than semisolid culture media (Escalant et al. 1994; López 2006).

7. LD50 calculations are preferably completed during the germination phase due to the low synchronization of the plant regeneration system during embryo histodifferentiation (López et al. 2007). It is also important to consider that the closest irradiation dose (lower and upper) to the LD50 is more likely to produce favorable mutants (Kulkarni et al. 2007). 
Acknowledgements Funding for this work was provided by the Food and Agriculture Organization of the United Nations and the International Atomic Energy Agency through their Joint FAO/IAEA Programme of Nuclear Techniques in Food and Agriculture through Research Contract No.15503 of IAEA Coordinated Research Project D24012, and from "Centro de Aplicaciones Tecnológicas y Desarrollo Nuclear" (CEADEN) in Cuba. We thank profusely Dr. Brad Till and Dr. Chikelu Mba for their valuable suggestions and help and to technicians Nery Montano and Damicela Reinaldo for their significant contribution to the protocols described here.

Open Access This chapter is distributed under the terms of the Creative Commons AttributionNoncommercial 2.5 License (http://creativecommons.org/licenses/by-nc/2.5/) which permits any noncommercial use, distribution, and reproduction in any medium, provided the original author (s) and source are credited.

The images or other third party material in this chapter are included in the work's Creative Commons license, unless indicated otherwise in the credit line; if such material is not included in the work's Creative Commons license and the respective action is not permitted by statutory regulation, users will need to obtain permission from the license holder to duplicate, adapt or reproduce the material.

\section{References}

Aguilar ME, Ortiz V, Sandoval JA (2008) Embriogénesis somática en plátanos y bananos: perspectivas y limitaciones. In: Turrialba CR (ed) CATIE-Serie técnica. Boletín técnico CATIE No. 27, $50 \mathrm{p}$

Arnold SV, Sabala I, Bozhkov P, Dyachok J, Filonova L (2002) Developmental pathways of somatic embryogenesis. Plant Cell Tiss Org Cult 69:233-249

Bakry F, Carreel F, Jenny C, Horry JP (2009) Genetic improvement of banana. In: Jain SM, Priyadarshan PM (eds) Breeding plantation tree crops: tropical species. Springer, New York, pp. $3-50$

Carlier J, De Waele D, Escalant JV (2003) Global evaluation of Musa germplasm for resistance to Fusarium wilt, Mycosphaerella leaf spot diseases and nematodes. Performance evaluation. In: Vézina P, Picq C (eds) INIBAP technical guidelines 7. The International Network for the Improvement of Banana and Plantain, Montpellier, $62 \mathrm{p}$

Cronauer S, Krikorian AD (1988) Plant regeneration via somatic embryogenesis in the seeded diploid banana Musa ornata Roxb. Plant Cell Rep 7:23-25

Dhed'a D, Dumortier F, Panis B, Vuylsteke D, De Langhe E (1991) Plant regeneration in cell suspension cultures of the cooking banana cv. Bluggoe (Musa spp. ABB group). Fruits 46: $125-135$

Escalant JV, Teisson C (1988) Embryogenèse somatique chez Musa sp. Physiol Végétale 306(3) $: 277-281$

Escalant JV, Teisson C, Côte F (1994) Amplified somatic embryogenesis from male flower of triploid banana and plantain cultivars (Musa spp). In Vitro Cell Dev Biol 30:181-186

Gómez R, de Feria M, Posada L, Gilliard T, Bernal F, Reyes M, Chávez M, Quiala E (2002) Somatic embryogenesis of the banana hybrid cultivar 'FHIA-18' (AAAB) in liquid medium and scalep-up in a bioreactor. Plant Cell Tiss Org Cult 68:21-26

Grapin A, Ortiz JL, Domergue R, Babeau J, Monmarson S, Escalant JV, Teisson C, Côte F (1998) Establishment of embryogenic callus and initiation and regeneration of embryogenic cell suspensions from female and male immature flowers of Musa. INFOMUSA 7(1):13-15

INIBAP. (1996) Descriptors for Banana (Musa spp). International Plant Genetic Resources Institute, Rome/International Network for the Improvement of Banana and Plantain, Montpellier, pp $1-55$ 
Jain SM (2007) Recent advances in plant tissue culture and mutagenesis. Acta Hort 736:205-211

Jain SM (2010) In vitro mutagenesis in banana (Musa spp.). In: Dubois T (eds) Improvement. Proceedings of IC on banana and plantain in Africa. Acta Horticulture, vol 879, pp 605-614.

Jain SM, Maluszynski M (2004) Induced mutations and biotechnology in improving crops. In: Mujib A, Cho MJ, Predieri S, Banerjee S (eds) In vitro application in crop improvement. Science, London, pp. 170-202

Jain SM, Swennen R (2004) In: SM J, Swennen R (eds) Banana improvement: cellular, molecular biology and induced mutation. Science, Enfield, p. 382

Jankowicz-Cieslak J, Huynh OA, Brozynska M, Nakitandwe J, Till BJ (2012) Induction, rapid fixation and retention of mutations in vegetatively propagated banana. Plant Biotechnol $\mathrm{J}$ 10(9):1056-1066. doi:10.1111/j.1467-7652.2012.00733.x

Kamle M, Bajpai A, Chandra R, Kalim S, Kumar R (2011) Somatic embryogenesis for crop improvement. GERF Bull Biosci 2(1):54-59

Kulkarni VM, Ganapathi TR, Bapat VA, Rao PS (2004) Establishment of cell-suspension cultures in banana cv. Grand Naine and evaluation of its sensitivity to gamma-irradiation. Curr Sci 86:902-904

Kulkarni VM, Ganapathi TR, Suprasanna P, Bapat VA (2007) In vitro mutagenesis in banana (Musa spp.) using gamma irradiation. In: SM J, Häggman H (eds) Protocols for micropropagation of woody trees and fruits. Springer, Dordrecht, pp. 543-559

López J (2006) Nueva metodología para el desarrollo de la embriogénesis somática en el cultivar de plátano vianda 'Navolean' (Musa spp., Grupo AAB), tesis de Doctorado. Centro de Bioplantas. Universidad de Ciego de Ávila, $100 \mathrm{p}$

López J, Gómez R, Rayas A, Montano N, Reinaldo D, Rayas A, Trujillo R, Cabrera M, Santos A, Ventura JC, Medero V, García M, Basail M, Albert J (2005a) Embriogénesis somática en el cv. 'Navolean' a partir de ápices de brotes de yemas axilares. Biotecnol Veg 5(2):109-113

López J, Gómez R, Toledo H, Montano N, Rayas A, Reinaldo D, Trujillo R, Chong B, Cabrera M, Santos A, Ventura JC, Medero V, García M, Basail M, Albert J (2005b) Evaluación en campo de plantas regeneradas por embriogénesis somática a partir de ápices de brotes de yemas axilares en cv. 'Navolean' (Musa spp., AAB). Biotecnol Veg 5(2):115-119

López J, Montano N, Reinaldo D, Rayas A, Toledo H, Sánchez R, Roux N (2007) Development of a methodology for the propagation of Calcutta 4 and plantain genotypes from embryogenic cell suspensions and its interface with mutation breeding. In: Report of the second research co-ordination meeting of FAO/IAEA/BADC co-ordinated research project, Kuala Lumpur. IAEA, Vienna, pp 49-56

López J, Montano N, Reinaldo D, Rayas A, Medero V, Santos A, Rodríguez D, Basail M, Beovides Y, Cantero A, Montano D (2013) Somatic embryogenesis for the production of plantain planting materials in Cuba. In: Ruane J, Dargie JD, Mba C, Boettcher P, Makkar HPS, Bartley DM, Sonnino A (eds) Biotechnologies at work for smallholders: case studies from developing countries in crops, livestock and fish. FAO, Roma, pp. 47-55

Ma SS (1991) Somatic embryogenesis and plant regeneration from cell suspension culture of banana. In: Symposium on tissue culture of horticultural crops. (1988, Taipei, Taiwan). Proceedings. Taiwan, National Taiwan University, pp 181-188

Murashige T, Skoog F (1962) A revised medium for rapid growth and bioassays with tobacco tissue culture. Physiol. Plant 15:473-497

Novak FJ, Afza R, Van Duren M, Perea-Dallos M, Conger BV, Xiolang T (1989a) Somatic embryogenesis and plant regeneration in suspension cultures of dessert (AA and AAA) and cooking (ABB) bananas (Musa spp.). Biotechnology 46:125-135

Novak F, Afza R, Van Duren M, Omar MS (1989b) Mutation induction by gamma irradiation of in vitro cultured shoot-tips of banana and plantain (Musa cvs). Trop Agric (Trinidad) 67:21-28

Okole B (2010) Mass-screening techniques for early selection of banana and plantain crops resistant to major disease and pests. In: Mass screening techniques for selection crops resistant to disease, IAEA-TDL-001, pp 47-58 
Parrott W (1993) Cell-culture techniques: cell culture, in vitro selection, and somaclonal variation. In: Proceeding biotechnology applications for banana and plantain improvement. Reunión INIBAP (1992, San José, Costa Rica). Montpellier, pp 183-191

Roux N (2004) Mutation induction in Musa-review. In: SM J, Swennen R (eds) Banana improvement: cellular, molecular biology and induced mutation. Science, Enfield, pp. 23-32

Roux N, Dolezel J, Swennen R, Zapata-Arias FJ (2001) Effectiveness of three micropropagation techniques to dissociate cytochimeras in Musa spp. Plant Cell Tiss Org Cult 66:189-197

Roux NS, Toloza A, Dolezel J, Panis B (2004) Usefulness of embryogenic cell suspension cultures for the induction and selection of mutants in Musa spp. In: Jain SM, Swennen R (eds) Banana improvement: cellular molecular biology and induced mutation. Science, Enfield, pp. 33-43

Sales E, López J, Espino R, Butardo N, González L (2013) Improvement of bananas through gamma ray irradiation. Philipp J Crop Sci 38(2):47-53

Sandoval JA, Pérez L, Cote F (1997) Estudio morfológico y de la estabilidad genética de plantas variantes de banano (Musa AAA cv. Gran Enano). CORBANA 22(48):41-60

Santos A, López J, Cabrera M, Montano N, Reinaldo D, Ventura JC, Medero V, García M, Basail M, Rayas A (2002) Obtención de embriones somáticos y establecimiento de suspensiones celulares embriogénicas en el clon de plátano 'Navolean' (AAB). Biotecnol Veg 2(2):107-109

Schoofs, H. (1997) The origin of embryogenic cells in Musa. Ph.D. thesis, KU Leuven, p 257

Schoofs H, Panis B, Strosse H, Mayo A, López J, Roux N, Dolezel J, Swennen R (1999) Bottlenecks in the generation and maintenance of morphogenic banana cell suspensions and plant regeneration via somatic embryogenesis therefrom. INFOMUSA 8(2):3-7

Strosse H, Domergue R, Panis B, Escalant JV, Cote FX (2003) Banana and plantain embryogenic cell suspensions. In: Vezina A, Pick C (eds) INIBAP technical guidelines 8. INIBAP, Montepellier, $36 \mathrm{p}$

Suprasanna P, Jain SM, Ochatt SJ, Kulkarni VM, Predieri S (2012) Applications of in vitro techniques in mutation breeding of vegetatively propagated crops. Technological innovations in major world oil crops 2: Perspectives, pp 371-385

Teisson C, Alvard D (1995) A new concept of plant in vitro cultivation liquid medium: temporary immersion. In: Terzi M, Cella R, Falavigna A (eds) Current issues in plant molecular and cellular biology. Kluwer Academic, Dordrecht, pp. 105-109

Van Harten AM (1998) Mutation breeding: theory and practical applications. Cambridge University Press, Cambridge, p. 353

Xu L, Najeeb U, Naeem MS, Wan GL, Jin ZL, Khan F, Zhou WJ (2012) In vitro mutagenesis and genetic improvement. In: SK G (ed) Technological innovations in major world oil crops, vol 2. Springer, Heidelberg, pp. 151-173 